\title{
Purification, properties and alternate substrate specificities of arginase from two different sources: Vigna catjang cotyledon and buffalo liver
}

\author{
Snehal Dabir ${ }^{1}$, Pankaj Dabir ${ }^{2}$ and Baburao Somvanshi ${ }^{1}$ \\ ${ }^{1}$ Department of Biochemistry, Dr BA Marathwada University, Aurangabad - 400001 (MS), India \\ ${ }^{2}$ Department of Biochemistry and JB Tropical Disease Research Centre, Mahatma Gandhi Institute of Medical Sciences, Sevagram \\ - 442 102, (MS), India
}

Corresponding address: Dr. Snehal Dabir, Phone: (+91)9822562943, E-mail: snehal_214@rediffmail.com

Received: 2005.03.10; Accepted: 2005.07.08; Published: 2005.08.01

Arginase was purified from Vigna catjang cotyledons and buffalo liver by chromatographic separations using Bio-Gel P150, DEAE-cellulose and arginine AH Sepharose 4B affinity columns. The native molecular weight of an enzyme estimated on Bio-Gel P-300 column for Vigna catjang was $210 \mathrm{kDa}$ and $120 \mathrm{kDa}$ of buffalo liver, while SDS-PAGE showed a single band of molecular weight $52 \mathrm{kDa}$ for cotyledon and $43 \mathrm{kDa}$ for buffalo liver arginase. The kinetic properties determined for the purified cotyledon and liver arginase showed an optimum $\mathrm{pH}$ of 10.0 and $\mathrm{pH} 9.2$ respectively. Optimal cofactor $\mathrm{Mn}^{++}$ion concentration was found to be $0.6 \mathrm{mM}$ for cotyledon and $2 \mathrm{mM}$ for liver arginase. The Michaelis-Menten constant for cotyledon arginase and hepatic arginase were found to be $42 \mathrm{mM}$ and 2 $\mathrm{mM}$ respectively. The activity of guanidino compounds as alternate substrates for Vigna catjang cotyledon and buffalo liver arginase is critically dependent on the length of the amino acid side chain and the number of carbon atoms. In addition to L-arginine cotyledon arginase showed substrate specificity towards agmatine and L-canavanine, whereas the liver arginase showed substrate specificity towards only L-canavanine.

K ey words: Purification, kinetic properties, substrate specificity arginine amidino hydrolase, Vigna catjang cotyledon, buffalo liver

\section{Introduction}

L-Arginase (L-arginine amidino hydrolase, EC 3.5.3.1.) is a binuclear manganese metalloenzyme that catalyzes the hydrolysis of L-arginine to form L-ornithine and urea. Arginase is the terminal enzyme of the urea cycle among the six enzymes. The enzyme was found to exist in two forms and has a broad tissue distribution. A cytosolic form, AI is highly expressed in the liver or hepatic cells and is important in ureogenesis. Extrahepatic AII form is thought to be involved in the biosynthesis of polyamines, the amino acids ornithine, proline and glutamate and in the inflammatory process, among others [1]. Recently studies have shown that increased stimulation of arginase expression in animal systems leads to production of polyamines that promote tumor cell proliferation [2] and wound healing [3].

Most of the studies on plant arginase have focused on its role in mobilizing arginine during early seedling germination. Storage proteins are mobilized to provide amino acids for protein synthesis in the expanding axis. Arginase activity increases sharply during germination in several species including soybean [4,5], arabidopsis and loblolly pines $[6,7]$. In higher plants urea and ornithine formed as products of arginase reaction are used in the assimilation of nitrogen into amino acids and the synthesis of polyamines through urease and ornithine decarboxylase respectively $[8,9]$. The enzyme has been isolated and characterized from cotyledons as well as axis of soybean $[5,8]$. But no properties of the purified enzyme from the cotyledons of Vigna catjang and buffalo liver have been reported. In animal's arginase is purified and characterized from a variety of sources having different characteristic properties with regard to molecular weight, subunit structure and its regulation especially in the urea cycle [10].
In contrast far less is known about the purification and properties of the enzyme in higher plants [11, 12]. Hence the present study was undertaken for the purification and properties of arginase from Vigna catjang cotyledon and buffalo liver, and also reports physicochemical and kinetic properties of the purified enzyme.

This purified enzyme can be used to study the effect of L-amino acids on the inhibition of arginases, to know the composition of amino acids at the active site of enzyme and may be useful in investigating its role in mobilizing the storage proteins.

\section{Materials and methods}

\section{Source of enzyme}

Seeds of cow pea Vigna catjang were obtained from the local market; surface sterilized by treating with Lysol, soaked in water for $6 \mathrm{hrs}$ and then allowed to germinate for $24 \mathrm{hrs}$ on moist filter paper at $25^{\circ} \mathrm{C}$.

Buffalo liver sample was collected from the local slaughterhouse. A portion of liver tissue was removed within 15 min after sacrificing the animal. It was placed in ice bath and brought to the laboratory as early as possible. The liver sample was immediately used for the isolation and purification of arginase.

\section{Cotyledon arginase activity assay}

Arginase activity was measured according to the Roman and Ruy's method [13]. Briefly the reaction mixture consisting of $10 \mathrm{mM}$ carbonate bicarbonate buffer (pH 10), $2 \mathrm{mM} \mathrm{MnCl}, 130 \mathrm{mM}$ L-arginine and enzyme solution in a total volume of $1 \mathrm{ml}$ was incubated for 30 minutes at $37{ }^{\circ} \mathrm{C}$. The reaction was terminated by adding $10 \%$ TCA. Protein was removed by centrifugation; $1 \mathrm{ml}$ of the supernatant was mixed with $1 \mathrm{ml}$ of anhydrous glacial acetic acid and ninhydrin reagent. The mixture was kept 
in boiling water bath for $20 \mathrm{~min}$. The intense red colour developed was diluted with $2 \mathrm{mls}$ of glacial acetic acid. The reagent blank was run in a parallel way and the results were compared with control assay. The optical density was read at $515 \mathrm{~nm}$ on spectrophotometer (UV 160A Shimatzu, Japan.) against reagent blank. The activity of arginase was expressed in units. A unit of an enzyme activity is defined as that amount of an enzyme, which produces one $\mu$ mole of L-ornithine per min at $37{ }^{\circ} \mathrm{C}$.

\section{Liver arginase activity assay}

Enzyme assay and experimental conditions used for buffalo liver arginase were same as described above for Vigna catjang cotyledon arginase, except millimolar concentrations of $\mathrm{MnCl}_{2}(6 \mathrm{mM})$, L-arginine $(25 \mathrm{mM})$ and carbonate bicarbonate buffer ( $50 \mathrm{mM}, \mathrm{pH}$ 9.2).

\section{Protein determination}

The protein content of each fraction was determined by the method of Lowry et al. [14] with the bovine serum albumin (Sigma, USA) as standard.

\section{Purification of cotyledon arginase}

Purification of the enzyme was carried out at $0-4{ }^{\circ} \mathrm{C}$. The cotyledons $(100 \mathrm{gm})$ were homogenized in a chilled mixer with $300 \mathrm{ml}$ of $50 \mathrm{mM}$ Tris- $\mathrm{HCl}$ buffer ( $\mathrm{pH} 7.5)$ containing $0.6 \mathrm{mM} \mathrm{MnCl}_{2}, 100 \mathrm{mM} \mathrm{KCl}$ and $10 \%$ Glycerol. The homogenate was filtered through four layers of gauze and clarified by centrifugation at 13,000 rpm for $30 \mathrm{~min}$ at $4{ }^{\circ} \mathrm{C}$.

\section{Ammonium sulphate precipitation}

The supernatant was adjusted to $30 \%$ saturation with solid ammonium sulphate and stirred at $4^{\circ} \mathrm{C}$ for 5 hours. The solution was then centrifuged and the pellet was discarded. The supernatant was brought to $70 \%$ saturation with solid $\left(\mathrm{NH}_{4}\right)_{2} \mathrm{SO}_{4}$ and treated as above except that the pellet was retained. The pellet containing the enzyme was resuspended with $30 \mathrm{mls}$ of $10 \mathrm{mM}$ Tris- $\mathrm{HCl}$ buffer $(\mathrm{pH}$ 7.5) containing $0.6 \mathrm{mM} \mathrm{MnCl} 2$ and $10 \%$ glycerol. The extract was purified by centrifugation.

\section{Bio-Gel P-150 chromatography}

The clear supernatant was applied to a Bio-Gel P-150 column $(2 \times 80 \mathrm{~cm})$ equilibrated with Tris- $\mathrm{HCl}$ buffer $(10$ $\mathrm{mM}, \mathrm{pH} 7.5$ ) containing $0.6 \mathrm{mM} \mathrm{MnCl}_{2}$ and $10 \%$ glycerol. The enzyme was eluted using the same buffer with a flow rate of $12 \mathrm{ml}$ / hour.

\section{DEAE-cellulose chromatography}

Active fractions obtained from above step were applied to DEAE-cellulose (Sigma) column $(2.5 \times 12 \mathrm{~cm})$ previously equilibrated with Tris- $\mathrm{HCl}$ buffer $(10 \mathrm{mM}, \mathrm{pH}$ $7.5)$ containing $10 \%$ glycerol. The column was washed with the same buffer and the enzyme was eluted using a linear gradient of sodium chloride $(0-0.5 \mathrm{M})$ prepared in column-equilibrated buffer.

\section{Affinity chromatography}

Active fractions from above step were pooled and applied on a hydroxyapatite column $(1.2 \times 10 \mathrm{~cm})($ BioRad, USA) previously equilibrated with Tris- $\mathrm{HCl}$ buffer (10 mM, $\mathrm{pH} 7.5$ ) containing $0.6 \mathrm{mM} \mathrm{MnCl}_{2}$ and $10 \%$ glycerol followed by $15 \mathrm{ml}$ of $0.5 \mathrm{M} \mathrm{KCl}$ prepared in column equilibrating buffer. The flow rate of column was adjusted to $12 \mathrm{ml}$ / hour, each $1.0 \mathrm{ml}$ fractions were collected and its protein content and arginase activity were assayed.

\section{Purification of liver arginase}

Liver sample was weighed (30 gm) homogenized with $120 \mathrm{ml}$ of chilled Tris- $\mathrm{HCl}$ buffer $(100 \mathrm{mM}$, pH 7.5) containing $5 \mathrm{mM} \mathrm{MnCl} 2$ and $100 \mathrm{mM} \mathrm{KCl}$. The homogenate was centrifuged at 13,000 rpm, 30 minutes and the supernatant was collected.

\section{Heat treatment}

The heat treatment was given to the above supernatant at $60{ }^{\circ} \mathrm{C}, 20 \mathrm{~min}$ with swirling. It was then immediately cooled in ice bath and denatured proteins were removed by centrifugation.

\section{Ammonium sulphate precipitation}

The resulting supernatant was adjusted to $30 \%$ saturation with solid $\left(\mathrm{NH}_{4}\right)_{2} \mathrm{SO}_{4}$ and stirred at $4{ }^{\circ} \mathrm{C}$ for 1 hour. The solution was then centrifuged and the pellet was discarded. The supernatant was brought to $70 \%$ saturation with solid ammonium sulphate and treated as above except that the pellet was retained. The pellet was resuspended in $15 \mathrm{mM}$ Tris- $\mathrm{HCl}$ buffer $\mathrm{pH} 8.0$ containing $5 \mathrm{mM} \mathrm{MnCl}_{2}$ and kept for 2 hours. The unresolved proteins were removed by centrifugation and dialyzed against the Tris- $\mathrm{HCl}$ buffer used for homogenization.

\section{DEAE-cellulose chromatography}

The dialyzed material was applied to a $2.5 \times 12 \mathrm{~cm}$ column of DEAE-cellulose (Sigma) at $4{ }^{\circ} \mathrm{C}$, equilibrated with the Tris- $\mathrm{HCl}$ buffer $(15 \mathrm{mM}, \mathrm{pH} 8.0)$ containing 2 $\mathrm{mM} \mathrm{MnCl} 2$. Elution was carried out with a linear gradient of $\mathrm{NaCl}$ from 0 to $0.5 \mathrm{M}$ in same buffer containing $2 \mathrm{mM}$ $\mathrm{MnCl}_{2}$ at a flow rate of $20 \mathrm{ml} /$ hour. The active fractions containing arginase activity were pooled together.

\section{Bio-Gel P-150 chromatography}

Above pooled fractions were dialyzed against Tris$\mathrm{HCl}$ buffer (15 mM, pH 8.0) containing $2 \mathrm{mM} \mathrm{MnCl}_{2}$ and applied as a concentrated zone on Bio-Gel P-150 (2 X 80 $\mathrm{cm})$ column equilibrated with Tris- $\mathrm{HCl}$ buffer $(15 \mathrm{mM}, \mathrm{pH}$ 8.0) containing $2 \mathrm{mM} \mathrm{MnCl}_{2}$. Each $2 \mathrm{mls}$ of fractions were collected at $12 \mathrm{ml} /$ hour and active fractions containing arginase activity were pooled.

\section{Affinity chromatography}

The pooled fractions from above step were dialyzed at $4{ }^{\circ} \mathrm{C}$ in $3 \times 3 \mathrm{~L}$ of Tris- $\mathrm{HCl}$ buffer $(15 \mathrm{mM}, \mathrm{pH} 8.0)$ containing $2 \mathrm{mM} \mathrm{MnCl}$ and passed through the arginine AH-Sepharose 4B $(1.2 \times 10 \mathrm{~cm})$ column equilibrated with $15 \mathrm{mM}$ Tris- $\mathrm{HCl}$ buffer $\mathrm{pH} 8.0$ containing $1 \mathrm{mM}$ $\mathrm{MnCl}_{2}$. The column was washed with $20 \mathrm{mls}$ of equilibrating buffer without $\mathrm{MnCl}_{2}$. The adsorbed proteins were eluted by passing $20 \mathrm{mls}$ of $10 \mathrm{mM}$ Tris- $\mathrm{HCl}$ (pH 8.0), $10 \mathrm{mls}$ of $50 \mathrm{mM}$ Tris- $\mathrm{HCl}$ ( $\mathrm{pH} 7.5), 10 \mathrm{mls}$ of 50 $\mathrm{mM}$ Tris $-\mathrm{HCl}(\mathrm{pH} 8.5)$ and finally with $1.0 \mathrm{M}$ sodium chloride in column equilibrating buffer. The fractions of 2 $\mathrm{ml}$ were collected with a flow rate of $12 \mathrm{ml} /$ hour and arginase activity and protein content were assayed.

\section{SDS-PAGE electrophoresis}

SDS-polyacrylamide gel electrophoresis (10\%) was carried out according to Laemmli et al (15). The purified enzyme was treated with $1 \%$ SDS and $\beta$-mercaptoethanol for 10 minutes at $100{ }^{\circ} \mathrm{C}$ and loaded in wells. Sample stacking was done at $10 \mathrm{mM}$ and resolution was carried out at $15 \mathrm{~mA}$ constant current. Molecular weight standards were bovine serum albumin $(66,000)$, Egg albumin (45,000), Glyceraldehydes triphosphate 
dehydrogenase $(35,000)$, Carbonic anhydrase $(29,000)$ and $\beta$-lactoglobuline $(18,400)$ (Sigma). After electrophoresis gel was stained in $0.25 \% \mathrm{w} / \mathrm{v}$ Coomassie brilliant blue (R-250) prepared in $50 \% \mathrm{v} / \mathrm{v}$ methanol and $10 \% \mathrm{v} / \mathrm{v}$ acetic acid. The gels were destained by passive diffusion of dye in $50 \% \mathrm{v} / \mathrm{v}$ methanol and $1 \%$ acetic acid after changing the destaining solution for 2-3 times.

\section{Native molecular weight determination}

The molecular weight of the purified enzyme was estimated by gel filtration with a Bio-Gel P-300 column $(2.2 \times 78 \mathrm{~cm})$. Blue dextran was used to measure the void volume. Catalase (bovine) $(2,40,000)$, Aldolase (rabbit muscle) (147,000), Albumin (bovine serum) $(67,000)$, Albumin (egg) $(45,000)$, Chymotrypsinogen A $(25,000)$ and Cytochrome $C(12,300)$ were used as a molecular weight marker. The elution volume of arginase was determined by estimating enzymatic activity whereas the protein content of each fraction was determined by Lowry's method [14]. The position of each marker protein was defined by plotting the elution volume against protein concentration. The molecular weight of an arginase was estimated by plotting log of molecular weight versus Kav for the standards. Kav $=(\mathrm{Ve}-\mathrm{Vo}) /(\mathrm{Vt} \mathrm{Vo})$, where $\mathrm{Vo}$ is the void volume of the column; $\mathrm{Vt}$ is the total volume of the column and Ve is the elution volume of a protein.

\section{Effect of $\mathbf{p H}$ on arginase activity}

The $\mathrm{pH}$ dependence of the enzymatic activity of arginase from cotyledon and liver were determined by using three buffer systems: $10 \mathrm{mM}$ Potassium phosphate ( $\mathrm{pH} 6.0$ to 6.5), Tris- $\mathrm{HCl}$ ( $\mathrm{pH} 7.0$ to 9.0) and carbonate bicarbonate buffer ( $\mathrm{pH} 9.0$ to 11.0).

\section{Effect of divalent cations}

To know the effect of divalent cations on the activity of arginase, the purified cotyledon arginase was diluted (1:2) with distilled water. The enzyme was dialyzed extensively with distilled water and further with $10 \mathrm{mM}$ Tris- $\mathrm{HCl}$ buffer ( $\mathrm{pH}$ 7.5) in the absence of manganese and then assayed the purified enzyme with the various metals.

The same procedure was followed to study the effect of different cations on the activity of buffalo liver arginase under the suitable enzyme assay conditions.

\section{Estimation of urea}

Arginase activity assay of the Vigna catjang cotyledon and hepatic tissue was carried out according to the procedure of Marsh WH et al. [16] by estimating urea. The reaction mixture consisted of $10 \mathrm{mM}$ carbonate bicarbonate buffer ( $\mathrm{pH}$ 10), $2 \mathrm{mM} \mathrm{Mncl}_{2}, 130 \mathrm{mM}$ Larginine and enzyme solution in a total of $1 \mathrm{ml}$ was incubated for 30 minutes at room temperature. This enzymatic reaction was terminated by adding $10 \%$ TCA. Two mls of reaction mixture was taken for urea estimation. The control tube was run simultaneously by inactivating the enzyme with $10 \%$ TCA prior to the addition of compound tested as alternate substrate (s) for arginase. The tubes were centrifuged, $2 \mathrm{ml}$ of the clear supernatant was transferred from each tube and the enzyme activity was recorded by spectrophotometric detection of urea at $520 \mathrm{~nm}$ by using diacetyl monoxime as described by Marsh WH et al. Enzyme assay and experimental conditions used for buffalo liver arginase were the same as described above for the Vigna catjang arginase, except millimolar concentrations of $\mathrm{MnCl}_{2}$ (6
$\mathrm{mM})$, L-arginine $(25 \mathrm{mM})$ and carbonate bicarbonate buffer (50 mM, pH 9.2).

\section{Substrate specificity}

The substrate specificity of Vigna catjang cotyledon and buffalo liver arginase was investigated by testing its activity towards structurally similar compounds with guanidino group. The agmatine, $\mathrm{d}$-arginine, L-arginine, $\mathrm{L}$ canavanine, L-argininic acid, $\beta$-guanidino propionic acid, $\gamma$-guanidino butyric acid, L-homoarginine and streptomycin (Sigma, USA.) tested as a potential alternate substrate for arginase. The solutions of above compounds (30 $\mathrm{mM}$ ) were prepared in $10 \mathrm{mM}$ carbonate bicarbonate buffer. Enzyme activity was measured by spectrophotometric detection of urea as described above.

\section{Results and Discussion}

\section{Purification}

The purification of arginase from Vigna catjang cotyledon and buffalo liver was carried out as described earlier 'Materials and Methods'. The results from the purification of arginase from cotyledons and liver are summarized in Table1. The fractional precipitation of arginase with chilled acetone $\left(-10^{\circ} \mathrm{C}\right)$ and heat treatment results in reduced stability of the cotyledon arginase, but fractional precipitation with ammonium sulphate yielded good results. It showed 2.2-fold purification corresponding to a specific activity of 70.15 . The enzyme fractions were freed of ammonium sulphate and low molecular weight protein by passing the solution through a Bio-Gel P-150 column. Arginase was adsorbed on a DEAE-cellulose column and eluted at about $300 \mathrm{mM}$ sodium chloride in column equilibrating buffer (Tris- $\mathrm{HCl}$, $10 \mathrm{mM}, \mathrm{pH} 7.5$ ) containing $0.6 \mathrm{mM} \mathrm{MnCl}_{2}$ and $10 \%$ glycerol. Inclusion of $10 \%$ glycerol in the column buffers has given stability to arginase activity during chromatographic purification. The enzyme was specifically bound on an arginine Sepharose 4B column and was eluted at a high molarity of Tris- $\mathrm{HCl}$ buffer (Figure 1). The specific activity of the arginase obtained from affinity column was about five fold higher than DEAE-cellulose chromatography. Probably arginine AHSepharose 4B minimized non-specific adsorption. The purification of Vigna catjang cotyledon arginase was achieved about 64 fold with $1.64 \%$ yield. This is about two and half fold lower than that reported for the axis of Soybean [5].

Arginase isozymes have not been reported in Iris bulbus and Pisum sativum and Jerusalem artichoke tubers [11, 12 ,17]. We could not find any evidence of the presence of arginase isozymes in purification steps.

Heat treatment was given to the crude extract of buffalo liver to enhance the coagulation of thermolabile proteins, which were further removed by centrifugation and supernatant was collected to test the enzymatic activity. It was found that arginase from buffalo liver was stable at $60{ }^{\circ} \mathrm{C}$. Such thermal stability of arginase has also been reported from livers of beef [18] and rabbit [19]. 70\% saturation of arginase with solid ammonium sulphate has resulted in increased specific activity of liver arginase. We did not observe any isozyme for buffalo liver arginase on DEAE-cellulose chromatography. The enzyme was eluted in a single symmetrical peak, with linear gradient of sodium chloride (Figure 2). The above active enzyme fractions were passed through Bio-Gel P-150 chromatography and a single homogenous peak of 
arginase activity was appeared. We have obtained about 2028.97 fold purification from arginine AH-Sepharose 4B affinity adsorbent (Table 1). The overall recovery was about $18 \%$. From the purification data it is clear that the protocol which we have used for the purification of Vigna catjang cotyledon and buffalo liver arginase is simple and effective.

\section{Molecular weight}

The molecular weight of the native enzyme determined by gel filtration was found to be $210 \mathrm{kDa}$ for Vigna catjang and $120 \mathrm{kDa}$ for buffalo liver arginase (Figure 3). The molecular weight on SDS-PAGE was found to be $52 \mathrm{kDa}$ and $43 \mathrm{kDa}$ for Vigna catjang and buffalo liver arginase respectively (Figure 4).

The molecular weight obtained for cotyledon arginase is smaller, compared with those of soybean axes $220 \mathrm{kDa}$ [5] and E. prunastri $330 \mathrm{kDa}$ [20]. Reports obtained for buffalo hepatic arginase agrees with the reported molecular weights of arginases from beef 115 $\mathrm{kDa}$ [18] and rabbit liver $110 \mathrm{kDa}$ [19].

\section{Kinetic properties}

The effect of incubation time on the activities of cotyledon and liver arginase was studied up to $75 \mathrm{~min}$. There was a direct relationship although not linear, between the product formed and incubation time for the enzymes. From the observations common incubation time selected for the studies was $30 \mathrm{~min}$.

Buffalo liver arginase is stable at $55-60{ }^{\circ} \mathrm{C}$ as in rat mammary gland [21] and rabbit liver [19], but in case of cotyledon arginase it is found to be less stable at the same temperature. The maximum activity of cotyledon and liver arginase was found at $35{ }^{\circ} \mathrm{C}$ and $42{ }^{\circ} \mathrm{C}$ respectively (Figure 5).

\section{Effect of pH}

The activity of cotyledon and liver arginase was determined in the buffer $\mathrm{pH}$ range from 6.0 to 11 at $37{ }^{\circ} \mathrm{C}$. The optimum $\mathrm{pH}$ of cotyledon arginase was found to be 10.0. This is found to be slightly higher than Evernia prunastri and Soybean axes $[5,20]$. Liver arginase showed high activity at $\mathrm{pH} 9.2$ (Figure 6). Generally mammalian arginases appear to have basic $\mathrm{pH}$ optima of 9.5-10.5, although some exceptions have been noted. Gasiorowska [22] have found four different isoenzymes of arginase in rat tissues, one of which had a $\mathrm{pH}$ optimum of 7.5. On the other hand, Patil et al [23] noted optimum pH 11.5 for Oxerythrocyte arginase at $55{ }^{\circ} \mathrm{C}$. The variation of activity with $\mathrm{pH}$ suggests that an ionisable group may function at the catalytic site [24].

\section{Michaelis-Menten constant (Km)}

The effect of substrate concentration on the activity of cotyledon and liver arginase was determined by Lineweaver-Burk, double reciprocal (1/V Vs 1/S) plots. The $\mathrm{Km}$ values for cotyledon and liver arginase were found to be $42 \mathrm{mM}$ and $2 \mathrm{mM}$ respectively as shown in figure 7 (A) and (B). The $\mathrm{Km}$ value of Vigna catjang cotyledon arginase is in the range of other reported $\mathrm{Km}$ $(40-83 \mathrm{mM})$ for plant arginases $[5,11,25]$. The $\mathrm{Km}$ value of buffalo liver arginase is in the range reported for type I arginase isolated from human $6.3 \mathrm{mM}$ [26] and rabbit liver [19]. A variation in millimolar concentration of arginine is may be due to the variety of assays used and nonphysiological conditions generally used [27, 28]. It is interesting to note that at a higher concentration of substrate, double reciprocal plot is non-linear and seems to indicate excess substrate inhibition in both Vigna catjang cotyledon and buffalo liver arginase.

\section{Effect of metal ions}

Arginase is a metallo enzyme in which manganese acts as a cofactor as well as activator in almost all reported arginases [20, 29]. However the amount required for optimal activity of the enzyme varies. About $0.6 \mathrm{mM}$ and $2 \mathrm{mM} \mathrm{Mncl}_{2}$ in the reaction mixture were found to be optimal for the activity of Vigna catjang and buffalo liver arginase respectively.

Replacement of $\mathrm{Mn}^{++}$ion with other metal ions such as $\mathrm{Mg}^{++}$and $\mathrm{Co}^{++}$restored more than $60 \%$ while $\mathrm{Ni}^{++}$and $\mathrm{Fe}^{++}$restored about $50 \%$ activity, whereas $\mathrm{Ca}^{++}$and $\mathrm{Zn}^{++}$ restored about 35 to $38 \%$ and $\mathrm{Cd}^{++}$restored only $10 \%$ of the original activity of Vigna catjang cotyledon arginase. In case of buffalo liver arginase, $\mathrm{Mg}^{++}$ions restored almost the original activity, whereas $\mathrm{Ca}^{++}, \mathrm{Ni}^{++}, \mathrm{Co}^{++}$and $\mathrm{Cd}^{++}$ restored about $40-50 \%$ of the original activity of the enzyme and $\mathrm{Fe}^{++}$and $\mathrm{Zn}^{++}$has completely inactivated the arginase activity (Table 2 ).

The amount of $\mathrm{Mn}^{++}$required for optimal activity of the soybean axes enzyme was reported as $1 \mathrm{mM}$ [5], 1-2 $\mathrm{mM}$ for human liver [30], 8-10 $\mathrm{mM}$ for human erythrocytes [31], $40 \mathrm{mM}$ for mammalian liver arginase [32] and $50 \mathrm{mM}$ for beef liver arginase [18]. Maggini et al [33] have measured arginase activity by reassessment of assay conditions using near physiological steady-state concentrations of arginine (5-35 $\mathrm{mM})$ and excess $\mathrm{Mn}^{++}$(30 $\mathrm{mM}$ ). They obtained specific activity values for rat liver arginase of $1.2 \mathrm{U} / \mathrm{g}$ of tissue, compared with activity values of $70 \mathrm{U} / \mathrm{g}$ from initial velocity experiments. This modified activity values suggest that arginase could play a role in the regulation of urea cycle activity, its activity being regulated by the concentrations of arginine and $\mathrm{Mn}^{++}$ions. Increased streptozotoein-induced in diabetic rat's resulted in activation of hepatic arginase [34]. Similarly, the concentration of manganese in the diet has been shown to regulate the activity of hepatic arginase in the rat [35].

\section{Substrate specificity}

Hepatic arginase of ureotelic and urecotelic animals have nearly same substrate specificity towards L-arginine and to some extent L-canavanine [36]. The leupine arginase hydrolyzes L-homoarginine more efficiently than L-arginine [37]. With this background it was interesting to investigate the substrate specificity of Vigna catjang cotyledon and buffalo liver arginase. Different substrates containing guanidino group common in their structure were tested as potential substrates for Vigna catjang cotyledon among these only agmatine, and L-canavanine were hydrolyzed significantly in addition to L-arginine. The ratio of the reaction product, urea of L-arginine to agmatine and L-arginine to L-canavanine is six and fifteen respectively Table 3. Arginase/canavanase high ratios $(>10)$ have been reported from arginase from rat liver [35] and silk moth [38] Table 3.

Buffalo liver arginase hydrolyzed only L-arginine and L-canavanine under the standard assay conditions and the results are shown in (Table 3). The ratio of Larginine to L-canavanine is more than ten. The enzyme does not hydrolyze the isomer of L-arginine, the $D$-arginine. Agmatine has no $\alpha$-carboxyl group, whereas $\gamma$-guanidino butyric acid and $\beta$-guanidino propionic acid 
lack $\alpha$-amino group. Streptomycin does not posses $\alpha-\mathrm{NH}_{2}$ as well as $\alpha-\mathrm{COOH}$ groups. Therefore buffalo liver arginase does not utilize these guanidine compounds as its substrate to liberate urea as one of the product.

\section{Conflict of interest}

The authors have declared that no conflict of interest exists.

\section{References}

1. Cederbaum SD, Yu H, Grody WW, et al. Arginase I and II: do their functions overlap? Med Genet Metab 2004; 81 (suppl 1):S38-44.

2. Chang CI, et al. Macrophage arginase promotes tumor cell growth and suppresses nitric oxide-mediated tumor cytotoxicity. Cancer Res 2001; 61:1100-1106.

3. Satriano J. Agmatine: At the Crossroads of the Arginine Pathways. Ann N Y Acad Sci 2003; 1009:34-43.

4. Kang JH, Cho YD. Purification and properties of arginase from soybean (Glycine max). Plant physiol 1990; 93:1230-1234.

5. Matsubara S, Suzuki Y. Arginase activity in the cotyledons of soybean seedlings. Plant physiol 1984; 62:309-314.

6. Zonia LE, et al. Essential role of arginase in germination of nitrogen limited Arabidopsis thaliana seeds. Plant physiol. 1995107 :10971103

7. King JE, Gifford DJ. Amino acid utilization in seeds of Loblolly pine during germination and early seedlings growth L-Arginine and arginase activity. Plant physiol. 1997; 113:1125-1135.

8. Dawnun KR, Rosenthal GA, Cohen WS. L-Arginine and Lcanavanine metabolism in jack bean, Canavalia ensiformis (L) DC and soybean, Glycine max (L) mere. Plant physiol 1983; 73:965-968.

9. Polacco JC, Holland MA. Roles of urease in plant cells. Int Rev Cytol 1993; 146:65-103.

10. Carvajal N, Ascoria M, Rodriguez JP, et al. Evidence of cooperative effects in human liver arginase. Biochim Biophys Acta 1982; 701:146-148.

11. Butin JP. Purification, properties and subunit structure of arginase from Iris bulbus. Eur J Biochem 1982; 127:237-243.

12. Wright LC, Brady GJ, Hinde RW. Purification and properties of arginase from Jerusalem artichoke tubers. Phytochem 1981; 20:2641 $-2645$.

13. Roman W, Ruys J. Simple method for the estimation of l-ornithine. J Clin. Enzyme 1969; 2:121-128.

14. Lowry OH, Roserbrough NJ, Farr AL, et al. Protein measurement with the Folin phenol reagent. J Biol Chem 1951; 193:265-275.

15. Laemmli UK. Cleavage of structural proteins during the assembly of the head of the bacteriophage T4. Nature 1970; 227:680-685.

16. Marsh WH, Fingerhut B, Miller H. Automated and manual direct methods for determination of urea. Clin Chem 1965; 11:624-627.

17. Talor AA, Stevart GR. Tissue and Subcellular localization of enzymes to arginine metabolism in Pisum sativum. Biochem Biophys Res Commun 1981; 101:1281-1289.

18. Harell D, Sokolovsky M. Beef-liver arginase. Isolation and molecular properties. Eur J Biochem 1972; 25:102-108.
19. George AK Harold JS. Isolation and characterization of arginase from rabbit liver. Biochem J 1973; 133:779-788.

20. Angels MF, Legaz ME. Purification and properties of the constitutive arginase of Evernia prunastri. Plant Physiol 1984; 76:1065-1069.

21. Christopher PJ, Murray RG. Rat mammary arginase: Isolation and characterization. Biochemical Med and Meta Biol 1994; 51:156-165.

22. Gasiorowska I, Porembaska Z, Jochimowicz J, et al. Isozymes of arginase in rat tissue. Acta Biochim Polon 1970; 17:19-30.

23. Patil NB, Somvanshi BS, Kothari RM. Isolation and characterization of arginase from Ox-erythrocyte. Biotech Tech 1990; 4 (2):133-136.

24. Kuhn NJ, Talbor J, Ward S. pH-sensitive control of arginase by Mn (II) ions at submicromolar concentrations. Arch Biochem Biophys 1991; 286:217-221.

25. Kollofel C, Van Dijke HD. Mitochondrial arginase activity form cotyledons of developing and germinating seeds of Vicia faba. Plant physiol 1975; 55:507-510.

26. Buscur L, Cabellow J, Veliz M, et al. Molecular forms of human liver arginase. Biochem Biophys Acta 1966; 128:149-154.

27. Ganganta CL, Bond JS. Assay and kinetics of arginase. Anal Biochem 1986; 154:388-394.

28. Pace CN, Buonanno A, Simmons - Hansen J. Steady-state kinetic studies of arginase with an improved direct spectrophotometric assay. Anal Biochem 1980; 109:261-265.

29. Helga HK, Greenberg DM. Molecular characteristics of rat liver arginase. J Biol Chem 1968; 243:6123.

30. Carvajal N, Venegas A., Ostreicher G, et al. The effect of manganese on the quaternary structure of human liver arginase. Biochim Biophys Acta 1971; 250:437- 442.

31. Nishibe H. Isolation and characterization of arginase in human erythrocyte. Physiol Chem Physics 1973; 54:53 - 462.

32. Hirsch-Kolb H, Kolb HJ, Greenberg DM. Comparative physical and chemical studies of mammalian arginase. Comp Biochem Physiol 1970; 37:345-359.

33. Maggini S, Stockin-Tschan FB, Morikofer-Zwez S, et al. New kinetic parameters for rat liver arginase measured at near physiological steady-state concentrations of arginine and Mn2+. Biochem J 1992; 283:53-660.

34. Bond JS, Failla ML, Unger DF. Elevated manganese concentration and arginase activity in livers of streptozotoein - induced diabetic rats. J Biol Chem 1983; 258:8004-8009.

35. Brock AA, Chapman SA, Ulman EA, et al. Dietary manganese deficiency decreases rat hepatic arginase activity. Nutrition 1994; 124:340-344.

36. Mora J, Tarrab R., Maratuscelli L, et al. Characteristics of arginases from ureotelic and non-ureotelic animals. Biochem J 1965; 96:588594.

37. Muszynska G, Reifer I. Purification, properties and inhibition of plant arginase. Acta Biochim Pol 1968; 15:55-66.

38. Reddy SRR, Campbell JW. Arginine metabolism in insects: properties of insect fat body arginase. Comp Biochem Physiol 1969; 28:515-534 


\section{Tables \& Figures}

Table 1. Purification of Arginase from Vigna catjang cotyledon and buffalo liver

(a) Vigna catjang

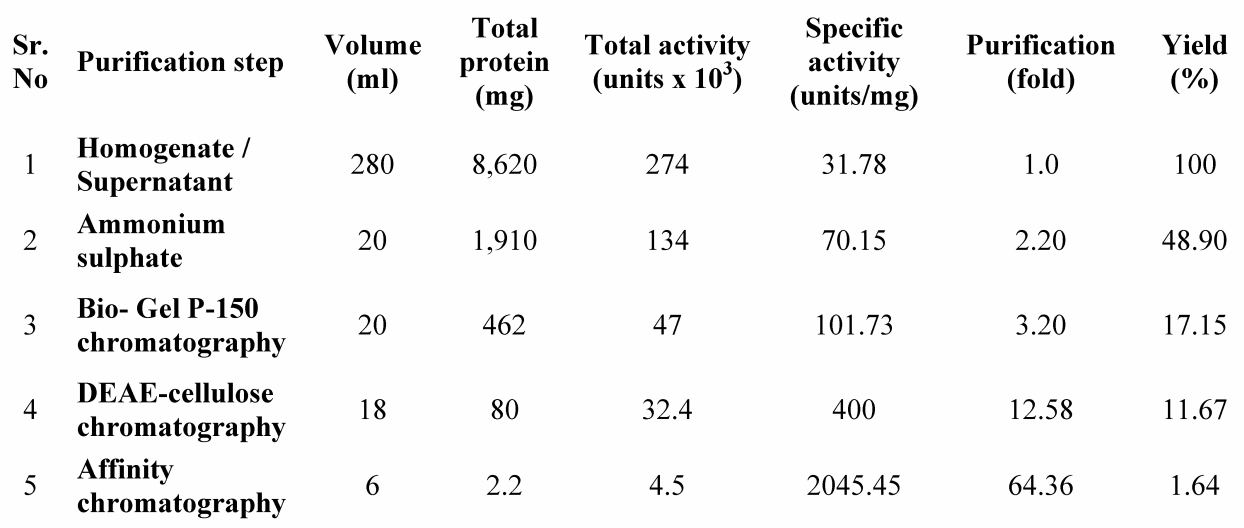

(b) Buffalo liver

\begin{tabular}{|c|c|c|c|c|c|c|}
\hline 1 Homogenate & 130 & 10,200 & 459 & 45 & 1.0 & 100 \\
\hline $\begin{array}{l}\text { Homogenate } \\
\text { supernatant }\end{array}$ & 90 & 2,367 & 450 & 190 & 4.22 & 98.03 \\
\hline Heat treatment & 69 & 584 & 365 & 625 & 13.88 & 79.52 \\
\hline $\begin{array}{l}\text { Ammonium } \\
\text { sulphate }\end{array}$ & 16 & 248 & 312 & 1,258 & 27.95 & 67.97 \\
\hline $5 \begin{array}{l}\text { DEAE-cellulose } \\
\text { chromatography }\end{array}$ & 34 & 30 & 253 & 8,433 & 187.40 & 55.11 \\
\hline $6 \begin{array}{l}\text { Bio-Gel P-150 } \\
\text { chromatography }\end{array}$ & 16 & 3.8 & 179 & 47,105 & 1046.77 & 38.99 \\
\hline $\begin{array}{l}\text { Affinity } \\
\text { chromatography }\end{array}$ & 8 & 0.92 & 84 & 91,304 & 2028.97 & 18.30 \\
\hline
\end{tabular}

Table 2. Effect of divalent cations on the activity of Vigna catjang cotyledon and buffalo liver arginase.

\begin{tabular}{|c|c|c|}
\hline \multirow{2}{*}{$\begin{array}{c}\text { Metal ion } \\
\text { mM }\end{array}$} & \multicolumn{2}{|c|}{$\begin{array}{c}\text { Residual activity } \\
(\%)\end{array}$} \\
\cline { 2 - 3 } & Cotyledon arginase & Liver arginase \\
\hline $\mathrm{Mn}^{++}$ & 100 & 100 \\
\hline $\mathrm{Mg}^{++}$ & 61 & 93 \\
\hline $\mathrm{Ca}^{++}$ & 35 & 52 \\
\hline $\mathrm{Co}^{++}$ & 66 & 45 \\
\hline $\mathrm{Ni}^{++}$ & 55 & 51 \\
\hline $\mathrm{Cd}^{++}$ & 11 & 43 \\
\hline $\mathrm{Fe}^{++}$ & 52 & 00 \\
\hline $\mathrm{Zn}^{++}$ & 38 & 00 \\
\hline
\end{tabular}


Table 3. Substrate specificities of Vigna catjang cotyledon and buffalo liver arginase

\begin{tabular}{|c|c|c|c|}
\hline \multirow{2}{*}{$\begin{array}{l}\text { Compounds } \\
(30 \mathrm{mM})\end{array}$} & \multirow{2}{*}{ Structure } & \multicolumn{2}{|c|}{ Urea in $\mu$ moles / min } \\
\hline & & Cotyledon & Liver \\
\hline Agmatin & $\begin{array}{c}\mathrm{H}_{2} \mathrm{~N}-\mathrm{C}-\mathrm{NH}-\left(\mathrm{CH}_{2}\right)_{4} \mathrm{NH}_{2} \\
\| \\
\mathrm{NH}\end{array}$ & 10.0 & 0.0 \\
\hline D-Arginine & $\begin{array}{cc} & \mathrm{NH}_{2} \\
\mathrm{H}_{2} \mathrm{~N}-\mathrm{C}-\mathrm{NH}-\left(\mathrm{CH}_{2}\right)_{3}-\mathrm{C}-\mathrm{COOH} \\
\| \mathrm{NH} & \mid \\
\end{array}$ & 0.0 & 0.0 \\
\hline L-Arginine & $\begin{array}{cc} & \mathrm{H} \\
\mathrm{H}_{2} \mathrm{~N}-\mathrm{C}-\mathrm{NH}-\left(\mathrm{CH}_{2}\right)_{3}-\mathrm{C}-\mathrm{COOH} \\
\| & \mid \\
\mathrm{NH} & \mathrm{NH}_{2} \\
\end{array}$ & 63.0 & 125.0 \\
\hline L-Homoarginine & $\begin{array}{cc} & \mathrm{H} \\
\mathrm{H}_{2} \mathrm{~N}-\mathrm{C}-\mathrm{NH}-\left(\mathrm{CH}_{2}\right)_{4}-\mathrm{C}-\mathrm{COOH} \\
\| & \mid \\
\mathrm{NH} & \mathrm{NH}_{2} \\
\end{array}$ & 0.0 & 0.0 \\
\hline L-argininic acid & \begin{tabular}{cl} 
& \multicolumn{2}{c}{$\mathrm{H}$} \\
$\mathrm{H}_{2} \mathrm{~N}-\mathrm{C}-\mathrm{NH}-\left(\mathrm{CH}_{2}\right)_{3}-\mathrm{C}-\mathrm{COOH}$ \\
$\|$ & $\mid$ \\
$\mathrm{NH}$ & $\mathrm{NH}_{2}$ \\
\end{tabular} & 0.0 & 0.0 \\
\hline L-Canavanine & $\begin{array}{cc} & \mathrm{H} \\
& \stackrel{\mid}{\mathrm{H}_{2} \mathrm{~N}-\mathrm{C}-\mathrm{NH}-\mathrm{O}\left(\mathrm{CH}_{2}\right)_{2}-\mathrm{C}-\mathrm{COOH}} \\
\| & \mid \\
\mathrm{NH} & \mathrm{NH}_{2} \\
\end{array}$ & 8.0 & 12.0 \\
\hline $\begin{array}{c}\gamma \text {-Guanidino butyric } \\
\text { acid }\end{array}$ & $\begin{array}{c}\mathrm{H}_{2} \mathrm{~N}-\mathrm{C}-\mathrm{NH}-\left(\mathrm{CH}_{2}\right)_{3}-\mathrm{COOH} \\
\| \\
\mathrm{NH} \\
\end{array}$ & 0.0 & 0.0 \\
\hline $\begin{array}{l}\beta \text {-Guanidopropionic } \\
\text { acid }\end{array}$ & $\begin{array}{l}\mathrm{H}_{2} \mathrm{~N}-\mathrm{C}-\mathrm{NH}-\left(\mathrm{CH}_{2}\right)_{2}-\mathrm{COOH} \\
\| \\
\mathrm{NH} \\
\end{array}$ & 0.0 & 0.0 \\
\hline Streptomycin & $\begin{array}{c}\mathrm{NH} \\
\| \\
\mathrm{H}_{2} \mathrm{~N}-\mathrm{C}-\mathrm{NH} \\
\mid \\
\mathrm{R} \\
\end{array}$ & 0.0 & 0.0 \\
\hline
\end{tabular}

Figure 1: Elution profiles of Vigna catjang arginase activity and protein content. A) Bio-Gel P-150 B) DEAE-cellulose and C) Arginine AH-Sepharose 4B chromatography.

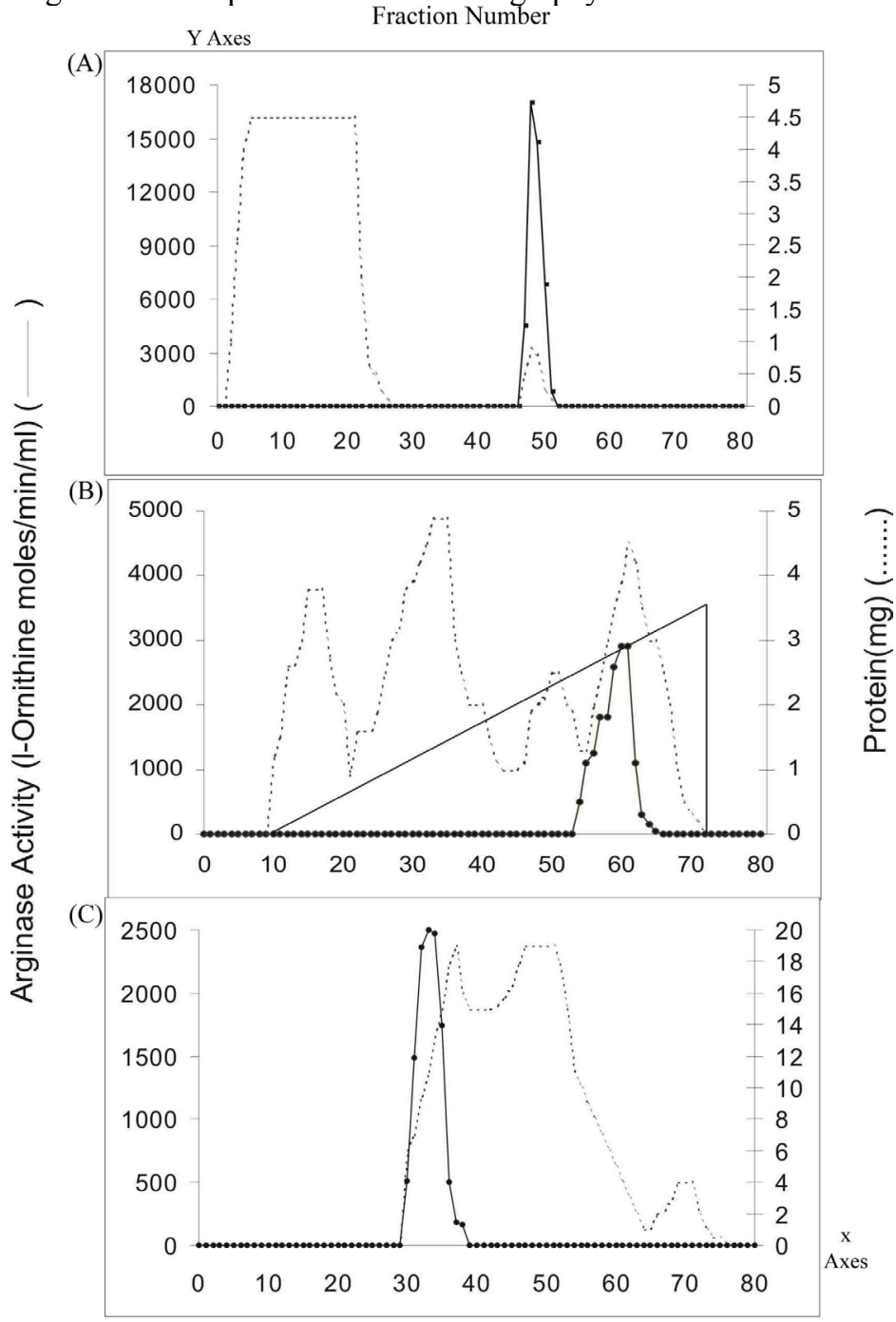


Figure 2: Elution profiles of Buffalo liver arginase activity and protein content. A) DEAE-cellulose B) Bio-Gel P-150 and C) Arginine AH-Sepharose 4B chromatography.

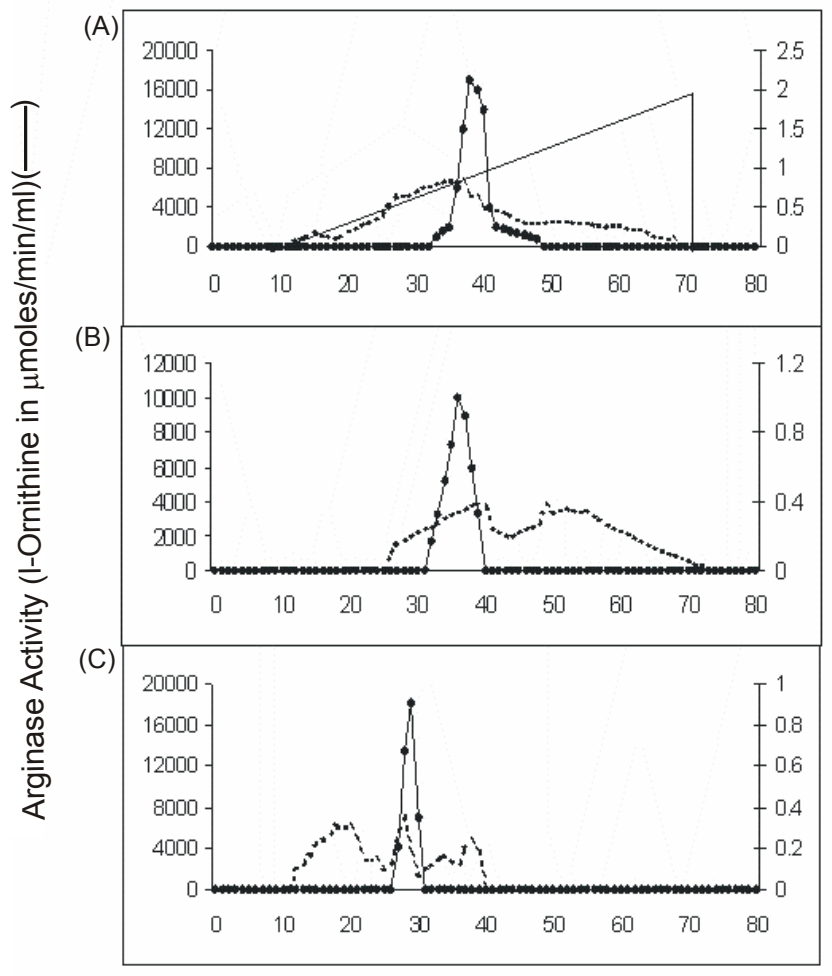

Fraction Number

Figure 3: Determination of molecular weight of Vigna catjang cotyledon (E) and Buffalo liver (E1) arginase by gel filtration technique on Bio-Gel P-300.

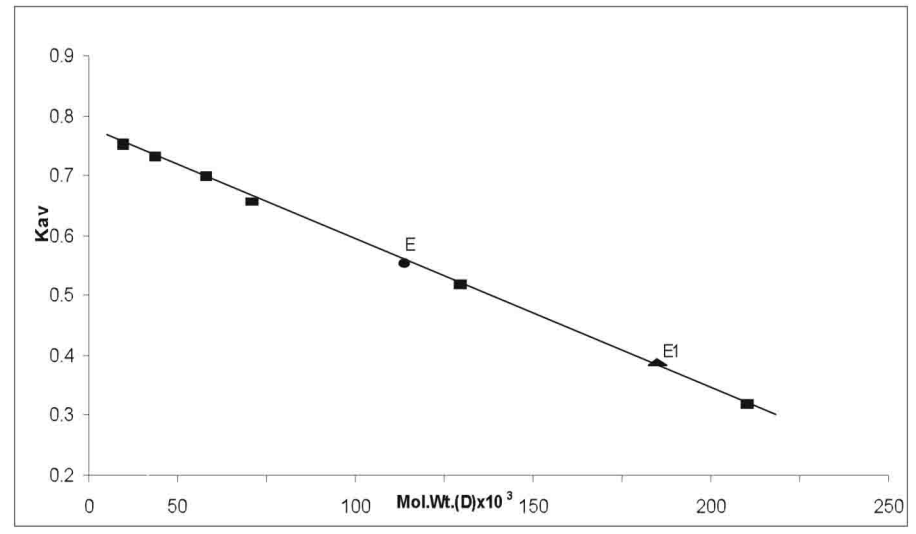

Figure 4: SDS-PAGE (10\%) analysis of purified Vigna catjang cotyledon and buffalo liver arginase. M: Molecular weight standard, size in kilodalton is shown on the left. A: Purified Vigna catjang cotyledon arginase and B: Purified buffalo liver arginase.

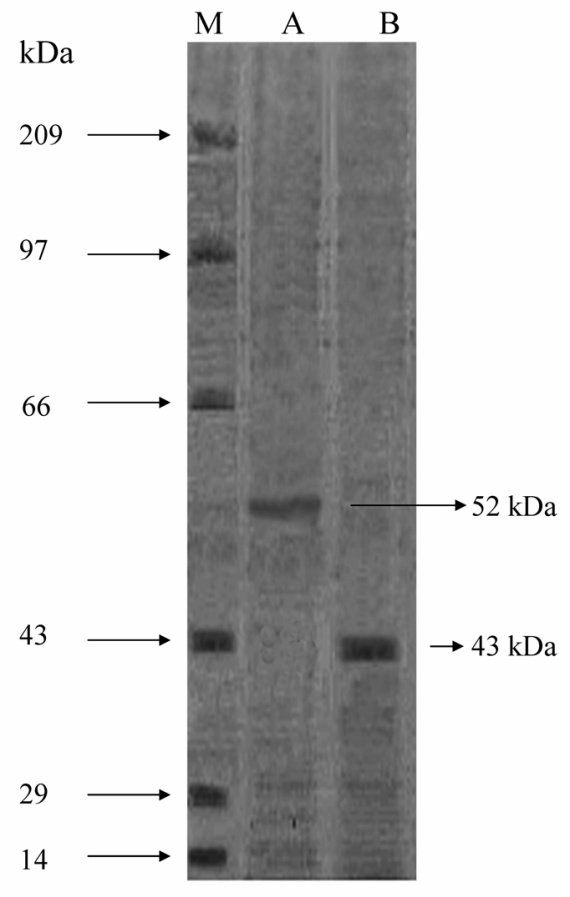

Figure 5: Determination of optimal temperature for the activity of Vigna catjang $(\bullet)$ cotyledon and buffalo liver ( $\bullet$ ) arginase. The data represents an average of multiple experiments.

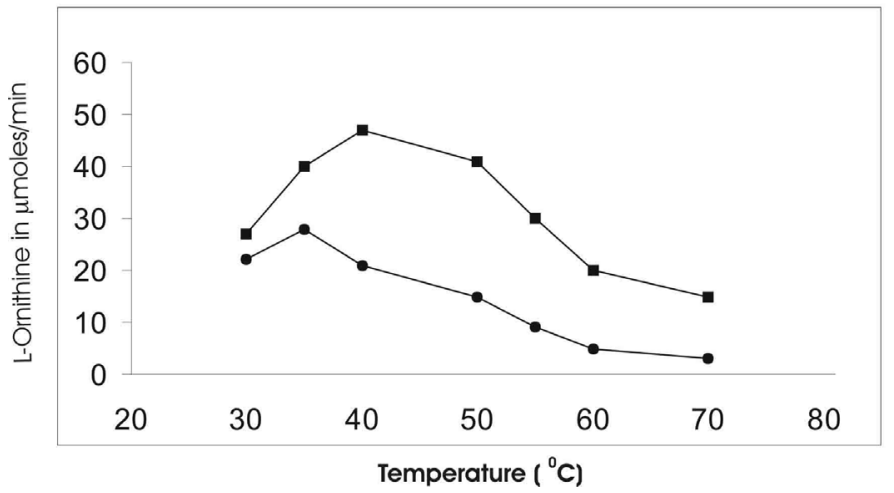

Figure 6: Determination of the optimal $\mathrm{pH}$ for Vigna catjang $(\bullet)$ cotyledon and buffalo liver ( $\bullet$ ) arginase. The enzymatic activity of arginase was determined by replacing the buffer in the $\mathrm{pH}$ range of 6.0-11.0. The data represents an average of multiple experiments.

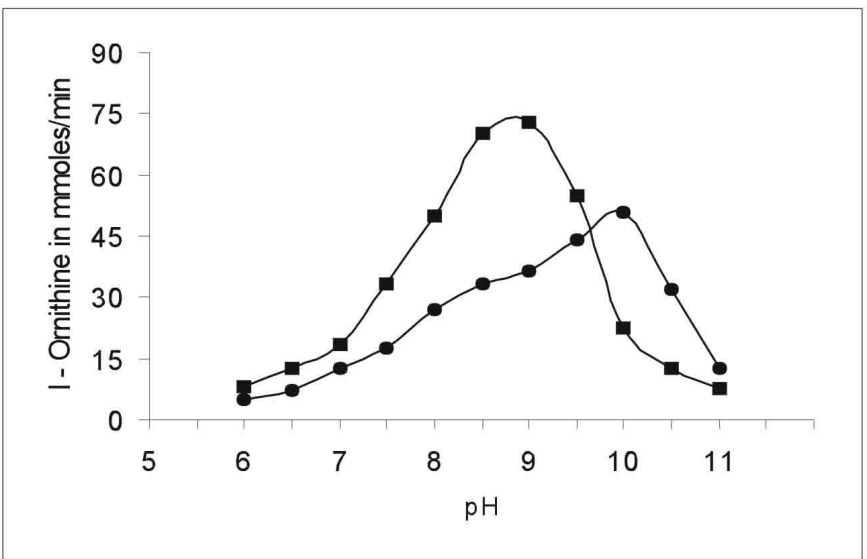


Figure 7: Linewaver-Burk plots of initial reaction velocities ( $\mu$ moles/min) for (A) Vigna catjang cotyledon and (B) buffalo liver arginase measured at various concentrations of arginine.

(A)

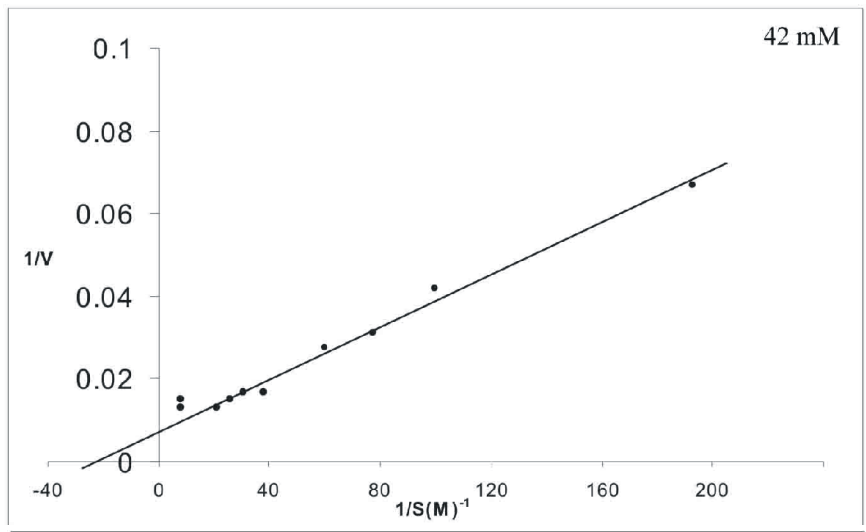

(B)

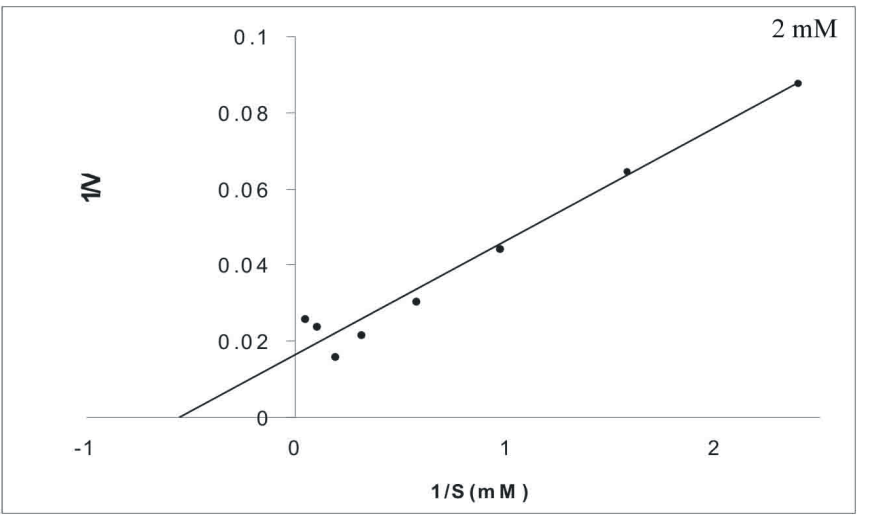

